\title{
A DECISION SUPPORT TOOL FOR CONTAINER TERMINAL OPTIMIZATION WITHIN THE BERTH SUBSYSTEM
}

\author{
Maja Stojaković, Elen Twrdy \\ Faculty of Maritime Studies and Transport, University of Ljubljana, Portorož, Slovenia \\ Submitted 17 October 2013; resubmitted 22 January 2014, 7 July 2014; accepted 23 August 2014 \\ first published online 14 January 2015
}

\begin{abstract}
The article deals with a current problem faced by all ports: how to enable container terminals to keep up with the development of container ships, which, due to economies of scale, are constantly increasing in size. One solution that can help small container ports solve this problem is a use of a Decision Support Tool (DST). The DST is based on simulations and identifications of the container terminal components that require optimization for the reception of the desired ship size in a given port. It consists of the six parts of the terminal that define the operational ship-to-shore system that determines the quality of service when a ship is in the port. A DST was tested on the real data of twelve Mediterranean container terminals. Special focus was made on the optimization possibilities of the container terminal in the port of Koper.
\end{abstract}

Keywords: container terminals; containership; decision support tool; operational performance; performance optimization.

\section{Introduction}

The port container terminals represent the points where containers are transferred from container ships to inland transporters and vice versa. Terminals are therefore trying to satisfy all the users of the sea-transport services with their infrastructural and equipment compositions (Dragović et al. 2006b). Its main functions are to receive outbound containers from shippers for loading onto vessels and to unload inbound containers from vessels for picking up by consignees, and, of course, the temporary storage of containers between ocean and land transportation (Van Hee, Wijbrands 1988; Murty et al. 2005).

Ship operation usually begins with the ship's arrival at the port area. After berthing, the ship-berth link handling operation begins with preparing the ship for loading/unloading and with the assignment of the proper number of quay cranes to the ship (Dragović et al. 2006b). Processes of the operations of the berth subsystem, as well as of two other subsystems of the terminal have been detailed by Vis and De Koster (2003), Murty et al. (2005) and others.

The number and capacity of ships able to enter a terminal in selected time is dependent on the technical equipment, layout and performance of a port, which may be judged by yearly throughput and position in the marketplace. Ports should therefore pay particular attention to the capacities and possible optimization of their container terminals, principally taking into account the size of the container terminal itself, its features, as well as the port's financial capabilities. In this context, the berth subsystem plays an important role as the factors of this subsystem are the first that ships encounter when arriving at the terminal and are therefore the most important indicators regarding the number and size of ships that can be accepted at the terminal, as well as the requirements for storage yard space and land equipment (Günther, Kim 2006).

The perpetual striving for cost cutting and the aim to achieve economies of scale has led ship-owners to construct ever larger container ships (Sys et al. 2008). Currently, the largest ship on the market is 18000 TEUs, while in a few years ships are expected to reach capacities of 22000 TEUs. Those trends also raise the demand for smaller (feeder) container vessels which have also been increasing over the last ten years and are now reaching sizes of 2800 TEUs (UNCTAD 2011, 2012). Today ship dimension represents a major problem for smaller container ports that do not have adequate equipment for the reception of such ships, yet at the same time, shipowners will demand facilitation of rapid transhipment

Corresponding author: Maja Stojaković

E-mail: maja.stojakovic@fpp.uni-lj.si 
and reduced costs in the ports. Since both container ships and container port facilities are very expensive, it is desirable to utilize them as intensively as possible (Dragović et al. 2006b). In fact, not all ports will ever be attractive for services that employ large ships; some of them simply do not have basic maritime conditions and enough cargo. Nevertheless, even if their aim for the future will be to remain 'just' a feeder port, they will be interesting for ocean carriers only when they will be able to offer their ships fast and efficient service.

Ports will therefore have to increase the capacities of their existing terminals. A key facet to improving the capacity of terminals will be making the correct decisions regarding the necessary changes. This paper focuses on the role that containership size has on terminal operations, especially on the berth subsystem, which with its restrictions has to enable rapid development of the port. The paper therefore presents the factors that play a key role in terminal optimization regarding the acceptance of larger ships.

In order to facilitate those decisions, a Decision Support Tool (DST) was created. The tool was originally built to support terminal operators (the decision maker) in their decisions regarding future investments in the improvement of the existing terminal capacities. The DST incorporates several terminal parts. The first three are the most important for determining the size of the ship that the port is able to accept, while all parts together are essential for the smooth processing of containers at the terminal. However, each has its own purpose, to function as an efficient whole a high level of interaction and consistency between them is necessary.

The DST is therefore suitable for use when the decision maker has to make strategic decisions and determine what the appropriate capacities of the elements at the berth subsystem are (sea depth, optimal quay length, adequate number of quay cranes) as well as to decide the right size of the storage area for the accommodation of a larger ship and for the optimal processing of the containers at the terminal.

The proposed DST is an analytical tool but at the same time, it is also an interactive tool as it enables the decision maker to vary the input of parameters to correctly arrive at his decisions.

The structure of the paper is organized as follows. The review of literature is discussed in Section 1. Section 2 presents the creation of a DST with a description of criteria and data. An analysis of the selected ports using a DST is provided in Section 3. The results of the analysis for ports evaluation using a DST are illustrated and discussed in Section 4. Optimization results for the port of Koper are provided in Section 5. Conclusions are presented in the last section.

\section{Review of Literature}

The literature reveals that many authors have investigated container terminal optimization. Steenken et al. (2004), and Stahlbock and Voß (2008), focused their research on container terminal operations and handling equipment. Vis and De Koster (2003), and Günther and Kim (2006), divided the container terminal into three decision-making levels and analysed the sequence of the terminal operations. Vacca et al. (2010), grouped the container terminal operations and decision problems into four main classes, namely berth allocation and scheduling, quay crane allocation and scheduling, transfer operations and storage and stacking. The paper provides a comparative analysis between a hierarchical and an integrated solution approach to two highly interdependent decision problems: the berth allocation problem and the quay crane assignment problem. Van Hee and Wijbrands (1988) developed a decision support system for capacity planning of container terminals. The DSS incorporates three models, each describing parts of the process of container handling at the terminal. While they focus more on the design phase, Murty et al. (2005) have developed a DSS for optimizing daily operations at Hong Kong container terminals. Dragović et al. (2006b) have, in their research monograph, pointed out some current problems in container terminals, including operations on the ship-berth link, and container yard modelling. They have developed and described simulation and analytical methodology to study the performance evaluation of the ship-berth link and a methodology for optimizing container yard operations. In the last ten years also other researchers have focused their studies on these specific operational problems at container terminals (Dai et al. 2008; Dragović et al. 2005, 2006a; Seyedalizadeh Ganji et al. 2010; Álvarez et al. 2010; Liang et al. 2012; Salido et al. 2012; Bierwirth, Meisel 2010), as well as storage space allocation (Zhang et al. 2003; Lee et al. 2006; Froyland et al. 2008).

On the other hand, Le-Griffin and Murphy (2008) analysed the productivity of the container terminal. Based on capacity statistics, four productivity measures have been used as initial points of comparison between numbers of leading container ports around the world. The authors have proved that these parameters can be used by port authorities for comparison with competing ports, and as a tool for making correct decisions regarding the optimization of their existing terminal capacity and ensuring greater productivity. Port efficiency and port competitiveness were also investigated by Tongzon and Heng (2005). Based on the existing literature they proposed eight key determinants of port competitiveness. Yeo et al. (2008) also studied container port competitiveness. They limited their study to the comparison between Korean and Chinese ports and selected 38 components for measuring the competitiveness between ports. Because of their generality, the components can be used in any port. By analysing those factors, it is clear that many of them are related to the terminal infrastructure and superstructure, which can be a limiting factor in increasing vessel size.

There has also been extensive literature on the relationship between containership size and terminal operations. Sys et al. (2008) in their paper gave a brief overview on the increasing container fleet market and explained the reasons for the deployment of ever larger 
container ships. They proved that the link between ship size and container terminal operations is very strong. Ports and terminals will therefore be facing new challenges and dealing with large investments in order to be able to accept the future post-Panamax ships. Jansson and Shneerson (1982) have done studies related to optimal ship size, while Cullinane and Khanna (1999) focused on the impact of ship size on unit costs; and later Kassembe and Gang (2011) focused on the economies of scale in large container ships.

Our study is based on the available data about newly ordered container ships, their characteristics in regard to draft, quay length and cranes necessary in the ports in order to be able to accept them.

Through the performed simulations, we created a decision-making tool that will indicate the parts of the container terminal that need to be optimized for a reception of the desired ship size in a single port. This tool consists of the six parts of the terminal that define the operational ship-to-shore system, which determines the quality of service when a ship is in the port.

\section{Setting up a DST}

Through a review of literature, we found that bottlenecks at container terminals can occur on the sea side as well as on the land side of the terminal, which includes storage areas and handover space. However, in this article we will focus only on the berthing area, as according to Sys et al. (2008) most related problems occur at the terminal in ship-to-shore relations.

It should be noted that smaller container terminals achieve lower productivity on the berth and storage subsystems, and are therefore at a position of disadvantage in the fight for attracting larger ships. This is directly related to the efficiency of cargo handling equipment and adequacy of the infrastructure on the berth and storage subsystem.

To determine the necessary measures that would provide greater capacity for container terminals in smaller ports and improve their competitiveness on the market we created a tool that supports ports in their decisions regarding future optimization.

The DST consists of real data and detailed research of infrastructure and cargo handling equipment in selected ports. Basic data were collected for twelve Mediterranean ports of different sizes. In order to develop a useful tool we selected some of the most successful ports in the Mediterranean, which in the last fifteen years had the highest growth in traffic and have similar characteristics (the first five ports in Table 1). These five ports served as an example for the medium and smaller ports (from 6 to 12 in Table 1) on which we tested the tool. The choice of ports was also conditioned by there being a sufficient amount of available primary data necessary for the tests.

The tool was therefore designed specifically for medium and smaller ports and serves as a support for the planning of future improvements and for adopting good practices from successful competitors.

For appropriate use of the tool, the characteristics of the determined ship size in the port are necessary. The key elements that define the size of the ship that can enter the port are thus sea depth, berth length, quay cranes, storage areas, land equipment and hinterland connections.

Although seaport container terminals differ considerably in size, function and geometrical layout, they principally consist of the same subsystems (Günther, Kim 2006). For the optimal functioning of the container terminal a high level of productivity and connection between the subsystems is of vital importance (Twrdy, Beškovnik 2008). According to Sys et al. (2008), besides the larger and deeper berth dimensions larger vessels will require container terminals to invest in larger cranes and also larger terminal areas; this illustrates that the berth subsystem is the first to take into account when optimizing the terminal capacities for the reception of larger ships. All the further processes on the other subsystems are therefore related to it.

Table 1. Technical characteristics of the ports

\begin{tabular}{|c|c|c|c|c|c|c|}
\hline No & Port & Throughput in 2012 [TEU] & Sea depth $[\mathrm{m}]$ & Berth length $[\mathrm{m}]$ & No of quay cranes & Storage area [ha] \\
\hline 1. & Marsaxlokk & 2540000 & $15.5 \div 17$ & 2308 & $23(p p+s p p)$ & 68 \\
\hline 2. & Piraeus & 2734014 & $12 \div 18$ & 2370 & $14(p p+s p p)$ & 72.4 \\
\hline 3. & Barcelona & 1749974 & $14 \div 16$ & 2460 & $23(p p+s p p)$ & 96 \\
\hline 4. & Gioia Tauro & 2721000 & $12.5 \div 18$ & 3,391 & $25(p p+s p p)$ & 155 \\
\hline 5. & Taranto $^{*}$ & 263461 & $14 \div 15.5$ & 2000 & $10(p p+s p p)$ & 25 \\
\hline 6. & Koper & 570744 & $11.4 \div 12$ & 600 & $8(p+p p)$ & 18 \\
\hline 7. & Rijeka & 129680 & $11 \div 12$ & 464 & $4(p)$ & 5.4 \\
\hline 8. & Trieste & 408023 & 18 & 770 & $7(\mathrm{pp})$ & 40 \\
\hline 9. & Ravenna & 208152 & 10.5 & 640 & $4(p)$ & 15 \\
\hline 10. & Varna & 128390 & $7.5 \div 9$ & 838 & $3(\mathrm{p})$ & 11.5 \\
\hline 11. & Odessa & 459720 & $11.5 \div 12.3$ & 1160 & $5(p+p p)$ & 4 \\
\hline 12. & Novorossiysk & 624000 & $8 \div 13$ & 566 & $2(\mathrm{p})$ & 14 \\
\hline
\end{tabular}

Notes: $\mathrm{p}$ - Panamax crane; pp - post-Panamax crane; spp - super-post-Panamax crane; ${ }^{\star}$ despite its low throughput, the port of Taranto was placed in a group of major ports due to its important transhipment function. 
Since the call of the ship in the port is conditioned mainly by the cargo handling equipment and work processes at the berth, those are the factors that determine the importance of the terminal on the market and the factors that directly define the size of the ships that can enter a port. The storage subsystem provides temporary storage of full and empty containers as well as their further shipment by sea or land, while the handover area is directly connected to the storage subsystem and is intended for loading and unloading of containers by or on road vehicles or railway wagons (Vis, De Koster 2003).

The first three elements of the DST are therefore part of the berth subsystem, while the other three belong to the storage subsystem and the subsystem of the handover area, which indirectly influences the size of the ship that can be received in port.

Vis and De Koster (2003) provide a detailed description of the processes at the three subsystems presented in Fig. 1. The figure illustrates the unloading and loading process at a typical modern container terminal. The processes can be divided into different sub-processes that explain the movement of containers when the ship enters the terminal, or, in the reverse order, when the export containers enter the port on the landside and have to be loaded onto a ship. The correct understanding of those sequences is of vital importance for understanding the sequences of the elements in the created DST.

\subsection{Choice Criteria}

For ocean carriers the selection of a container terminal or container port is a complex process. Wiegmans et al. (2008), define the basic criteria for the port choice as follows: port physical and technical infrastructure; geographical location; port efficiency; interconnectivity of the port; reliability, capacity, frequency and cost of inland transport services by truck; quality and costs of auxiliary services; efficiency and costs of port management and administration; availability, quality and costs of logistic value-added activities; availability, quality and costs of port community systems; port security and environmental profile of the port; and the port reputation. However, the most important factors that influence the ocean carriers in choosing a port remain the requirements of service quality, time at berth (transhipment time) and costs for loading and discharging (Steenken et al. 2004; Beškovnik 2008). On the other hand, a termi- nal operator aims to achieve a higher container throughput with fewer berths and less manipulation equipment. The decisions taken by the ocean carriers therefore have direct impact on the terminal system productivity and efficiency, in that, mostly, they are measuring the competitiveness of different maritime container terminals (Beškovnik 2008). The most frequent evaluating factors are related to the berth subsystem (water depth, berth availability, berth productivity, spent time on the berth and service capacity for the ship's size) and after that to the other subsystems.

Sea depth is the first and the most important factor in determining the size of the ship in the port, and therefore takes the first place in the DST. The historical development of container vessels shows that with the increase of ship capacity their draft also increases. It can be assumed that the larger the ship capacity, the greater the draft and, obviously, the greater the depth required at the terminal. Exceptions to the aforementioned rule are ships exceeding 14000 TEUs capacity. From here, draft is no longer increasing in proportion to the ship capacity. The characteristics of today's biggest ships and the newly planned ULCC ships (up to 18000 TEUs and 22000 TEUs) clearly show that the essential differences in this class will no longer be related to the draft but to the ship length, which is visibly increasing (Sys et al. 2008). The second limiting factor is therefore the berth length. This factor will be crucial for the biggest container terminals that already can accept ships of 10000 TEUs or more. Smaller terminals will still depend on sea depth. For them berth length will be important only if they obtain a larger number of direct services with bigger ships. In that case, the terminal will have to be long enough to accept two larger ships simultaneously. The third factor in the tool is related to the number of quay cranes and their dimensions. These are extremely important for the productivity of container ports. The productivity of container cranes is directly related to the time that ships spend at the berth and are therefore considered to be the most important machinery at the terminal (Watanabe 2001). For smaller ports, the purchase of new, more powerful, cranes is essential; otherwise, they would not be able to serve large ships due to the insufficient arm length of the existing cranes.

Storage areas and land equipment represent the fourth and the fifth factors of the tool. They are espe-

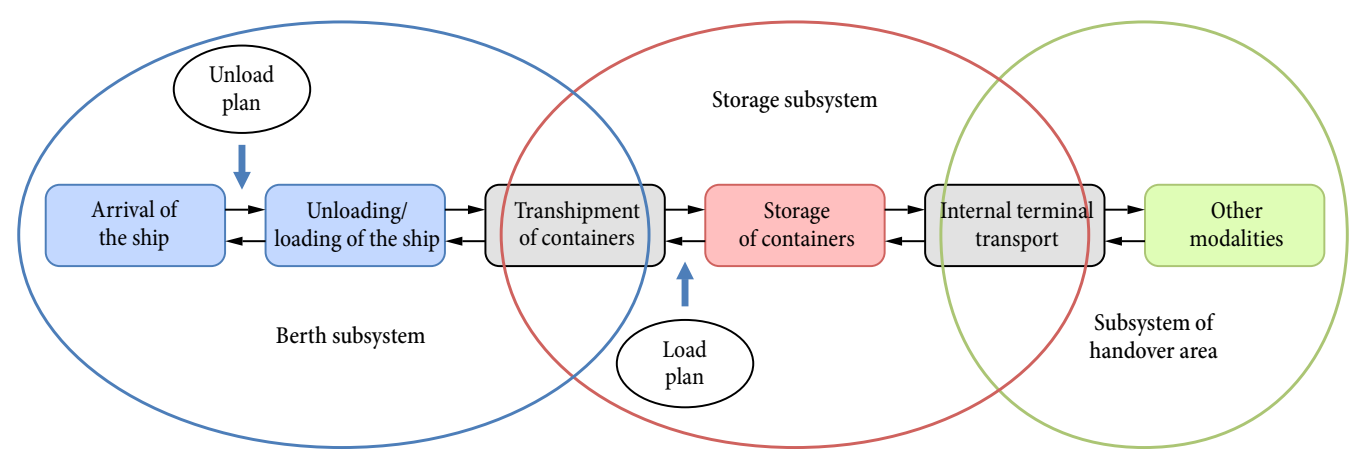

Fig. 1. Processes at a container terminal 
cially important for the origin-destination ports, as they significantly affect the level of the port efficiency (LeGriffin, Murphy 2008). The arrival of larger ships means a consequent increase in the trade flows in the port for which terminals need greater storage capacity and better equipment. We can confidently say that when the port needs a larger storage area this will almost certainly require more powerful land equipment as well. Therefore, these two factors are closely related and often inseparable. An increase in trade flows means also a need to improve hinterland connections of the terminal. In the opposite case, the terminal is exposed to productivity reduction, congestion and delays in the delivery of containers to the final costumers, or, in the reverse, to the terminal. Smaller ports are therefore often forced to optimize their existing connections with the hinterland in order to receive larger ships at the terminal; otherwise, the terminal will be subject to bottlenecks.

To use the tool correctly, the port or terminal operator must know the size of the ship he wants to receive in the port and the characteristics that the selected ship requires at the terminal. The proposed vessel has to be larger than the size of the ship that already can enter the port (Fig. 2).

It starts with the existing situation of the terminal. The parts of the terminal to examine are in order of importance so the terminal operator must focus firstly on the existing situation of the first factor. If the factor has the required capacity, it means that optimization in this part of the terminal is not needed and the operator moves down to examine the following factors of the tool. If the situation at the selected part does not have the re-

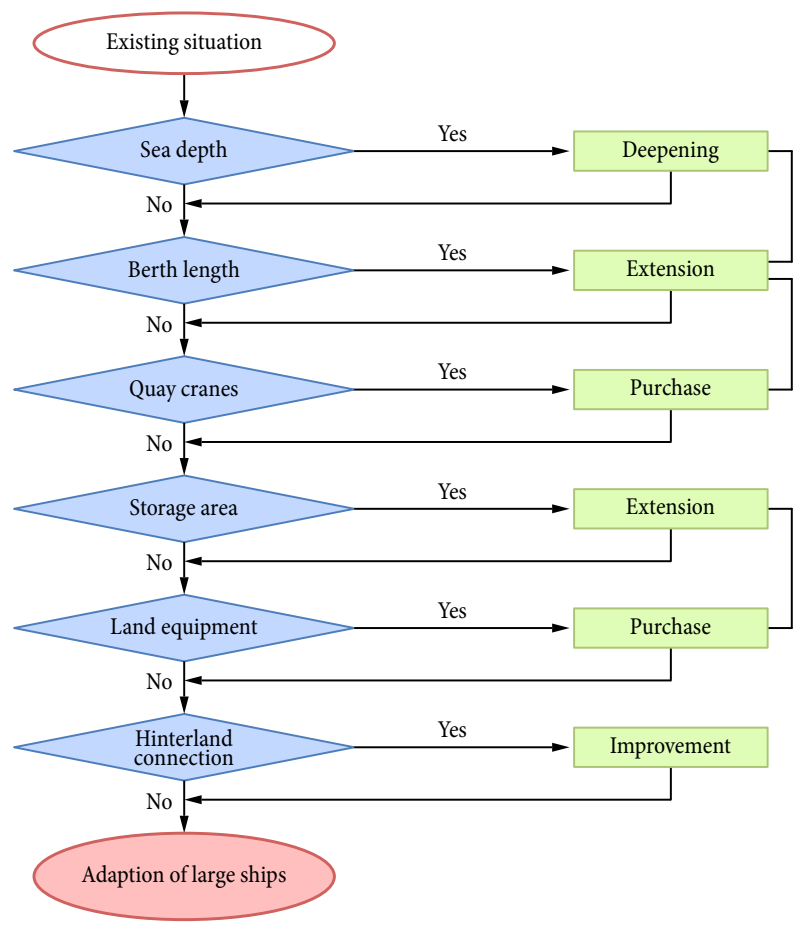

Fig. 2. Container terminal DST (in terms of ship capacity) quired capacities the operator moves right to determine which are the necessary measures to take, and only after that moves down to the following factor. When coming to the end the measures that have to be take into account for the reception of the desired ship size will be known.

On the bases of the technical characteristics of the ship's size and with the help of the tool it can therefore be established whether the capacity of the individual part of the container terminal is in a sufficient condition for the reception of the selected ship, or the capacity is insufficient and requires optimization.

The presented tool was created to facilitate the operator's work in order to rapidly arrive at the right solutions. Each port has its own requirements and priorities, but those are the factors that are common to all ports. Some ports will stop at the first criterion, when they realise that they do not have sufficient depth, when there follows a series of measures of which the main aim is deepening as soon as possible. We did not focus on those measures in the article, as we wanted only to present a tool that illustrates the sequence of criterion and their relations with each other.

With the help of the tool, ports can quickly identify those requirements that they are meeting today and what they have to improve to be interesting for the shipowners in the future.

\subsection{Data}

As previously mentioned, the simulation tool was developed using twelve Mediterranean ports. The choice of this area was conditioned mainly by the fact that ocean carriers prefer to use direct services with post-Panamax ships rather than operate on the hub and spoke principle on lines between the Far East and the Mediterranean Sea. For the smaller ports the adjustment of their existing capacities is therefore of vital importance if they want to preserve or improve their position on the market place.

For the purpose of the study, twelve ports of different sizes that cover different Mediterranean area (western and eastern part and the Black Sea) were chosen for which relevant data were available. The first five ports serve as a successful example for the smaller ports as they represent major ports of which throughput in 2012 exceeded one million TEUs, as well as transhipment ports. They are acting on the market as important regional and global shifting points (Beškovnik, Twrdy 2010). The second group mostly consists of the ports of which throughput in 2012 did not exceed 500000 TEUs and are therefore considered as smaller container ports with a regional transport function.

For decision-making on the basis of the DST we used a vessel of capacity 6000 TEUs. Due to the characteristics of the analysed ports, we came to the conclusion that this size is the most acceptable for all the ports and the one to be used in a direct line in the Mediterranean, even if a large number of ports lack adequate conditions for receiving this capacity. 
According to Sys et al. (2008), the requirements in a port for the acceptance of 6000 TEU ships are the following:

- sea depth - $13 \div 14 \mathrm{~m}$;

- channel depth - $13 \div 14 \mathrm{~m}$;

- berth length - $350 \mathrm{~m}$;

- storage area -16 ha per berth;

- quay cranes - post-Panamax (45 m outreach).

With the help of the presented DST it can be quickly determined at which part of the container terminal the port will need improvements to be able to accommodate ships of this size. Nevertheless certain obstacles (barriers) and challenges may arise. For appropriate use of the tool, it is in the first place necessary to assess the real capacities of the container terminal and to set the correct and current positions of the given terminal on the marketplace as well as to correctly predict the future development of the sector. If the estimates prove incorrect (the terminal is overrated), this could result in significant costs, which may affect the competitiveness of the terminal on the market. The implementation of the DST also depends on support received and resources. It is important, therefore, to have a good regulated financial construction. The port has to take into account factors such as terminal and hinterland capabilities, as the incorrect assessment of this situation may represent the danger that the terminal could develop faster than the hinterland. If the port plans are not coordinated with those of the development of infrastructure in the hinterland, it is likely to lead to bottlenecks and congestion in the port (or, perhaps worse, the opposite extreme).

\section{Analysis of the Selected Ports Using a DST}

The capacities of individual parts of the terminals in the above-listed ports were therefore analysed using the DST. The tool was tested first for the arrival of one 6000 TEU ship at the terminal and later for the simultaneous arrival of two ships of the same capacity. The results are shown in the following tables. In the fields with a value 1 the optimization of a certain part of the terminal is not needed as the current capacity is sufficient for the adoption of one 6000 TEU capacity ship, while fields with the value 0 indicates that optimization in a specific part of the terminal is necessary for the adoption of the mentioned ship capacity.

\subsection{Acceptance of One Vessel (6000 TEUs Capacity) in the Port}

Capacities of the major ports such as Piraeus and Barcelona, and transhipment ports such as Taranto, Marsaxlokk and Gioia Tauro, are entirely sufficient for accommodating ships of 6000 TEUs. Optimization for them is not necessary at any point of the tool. The results for these ports were actually expected, since in practice they serve as transhipment points in the Mediterranean. Their role is extremely important for smaller ports which do not have conditions for the reception of large ships and due to insufficient trade flows and natural-geographic properties of the ports they will be exposed to the same problem in the future. The results obtained using the DST are shown in (Table 2).

The results in the bottom part of the table, where smaller container ports were analysed, shows a slightly different situation. The sea depth is insufficient and must be increased in almost all of the analysed ports.

Capacity in the second factor - berth length - satisfies the conditions for the adoption of one large ship (approximately $300 \mathrm{~m}$ ) and at least one smaller ship (approximately $200 \mathrm{~m}$ ) at the same time, in the majority of the analysed ports. Extension of the berth under the above data is therefore not necessary if the pier length is at least $600 \mathrm{~m}$. The exception in the table is the Odessa port where the pier length is $1160 \mathrm{~m}$ and consists of four short berths $(310+230+270+350 \mathrm{~m})$, of which only the first two are used regularly for container traffic. The other two berths are allocated for container traffic only in exceptional cases. For these reasons, we estimated that with the current pier facilities the port is unable to receive 6000 TEU vessels, so the value in the field is 0 . New quay cranes are required in all those ports, except for Koper and Trieste, which are the only ports where a sufficient number of post-Panamax cranes already exists.

The results in the column of storage area and land equipment are in the case of the adoption of large ships exactly the same. The results showed that the optimization of the storage capacity and land equipment are not required in the ports where the current storage capacity is over $15 \mathrm{ha}$. Those are in our case only the ports of Koper, Trieste and Ravenna. In most ports, with the introduction of a new weekly direct service with a ship of 6000 TEU, the existing links with the hinterland would be sufficient. The exceptions in this case are only the ports of Rijeka and Odessa, which have problems with

Table 2. The results of the analysis according to the DST (one 6000 TEU ship)

\begin{tabular}{|c|c|c|c|c|c|c|c|}
\hline No & Port & 岂 & 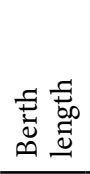 & 总芯 & 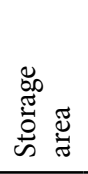 & 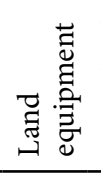 & 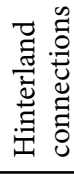 \\
\hline 1. & Marsaxlokk & 1 & 1 & 1 & 1 & 1 & 1 \\
\hline 2. & Piraeus & 1 & 1 & 1 & 1 & 1 & 1 \\
\hline 3. & Barcelona & 1 & 1 & 1 & 1 & 1 & 1 \\
\hline 4. & Gioia Tauro & 1 & 1 & 1 & 1 & 1 & 1 \\
\hline 5. & Taranto & 1 & 1 & 1 & 1 & 1 & 1 \\
\hline 6. & Koper & 0 & 1 & 1 & 1 & 1 & 1 \\
\hline 7. & Rijeka & 0 & 0 & 0 & 0 & 0 & 0 \\
\hline 8. & Trieste & 1 & 1 & 1 & 1 & 1 & 1 \\
\hline 9. & Ravenna & 0 & 1 & 0 & 1 & 1 & 1 \\
\hline 10. & Varna & 0 & 1 & 0 & 0 & 0 & 1 \\
\hline 11. & Odessa & 0 & 0 & 0 & 0 & 0 & 0 \\
\hline 12. & Novorossiysk & 0 & 0 & 0 & 0 & 0 & 1 \\
\hline
\end{tabular}

Notes: '0' - current capacities are insufficient, optimization is required; ' 1 ' - current capacities are sufficient, optimization is not required. 
the storage area. In such cases, the introduction of a new service with such a large number of containers would almost certainly represent a bottleneck in the transport of containers to the hinterland.

The study confirmed that smaller container ports would actually have to expand and optimize their existing capacity if they want to be more competitive and be able to accept larger container ships at the terminal. Our tool has shown that the key roles in terminal optimization will be played by the sea depth, quay cranes and storage areas. In cases where ports do not opt for the optimization of their terminal capacities, the most reasonable choice for them would be a specialization in feeder service, as the largest ships received would be limited to a maximum of 5000 TEUs. Due to the growing trends in container transport, this ship size will in the future be completely uninteresting to insert in a direct service.

\subsection{Acceptance of Two Vessels (6000 TEUs Capacity)} in the Port

In the second phase, the proposed tool was used to check the situation in selected ports with the arrival of two 6000 TEUs container ships at the terminal simultaneously. This situation could actually occur if the port acquired more direct services with ships of this size. The results obtained using the DST are shown in (Table 3).

The results for the group of the first five ports would remain the same. Even with the arrival of two 6000 TEU ships those ports would not require optimization at any point of the tool.

On the other hand, the results obtained in the smaller ports show that in the future those ports would have to continue to invest significantly to upgrade their facilities. The column of the sea depth remained the same as it was in the previous table, since the size of the ship has not changed, while the situation in the column of the berth length is quite different. The analysis shows that six ports would have to extend their quays. The exception is the port of Trieste, where the current quay length exceeds $700 \mathrm{~m}$. Varna and Odessa were also treated differently. In the case of Varna, the total length of the quay amounts to $838 \mathrm{~m}$, and is divided into two separate terminals $(500+338 \mathrm{~m})$, which prevents the reception of two large ships at the terminal simultaneously, while at Odessa the problem remains the same as in (Table 2). For those reasons, the value in the table is 0 .

The simultaneous work on two large container ships requires a considerable number of quay cranes (from 3 to 5 cranes per ship) at the terminal (Sys et al. 2008). It is therefore clear that all the analysed ports (with the exception of Trieste) would have to purchase new quay cranes. This applies for the ports that do not have adequate cranes yet, as well as for those that actually have these cranes (Koper and Odessa), but not in sufficient numbers given the arrival of two ships at the terminal. In the case that new cranes would not be purchased, the productivity at the berth subsystem would be dramatically reduced, which would consequently mean queues and lengthy stays of the ships at the berths.
Table 3. Results of the analysis according to the DST (two 6000 TEUs ships in the port)

\begin{tabular}{|c|c|c|c|c|c|c|c|}
\hline No & Port & $\stackrel{\mathscr{J}}{\tilde{z}}$ & 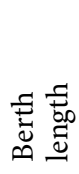 & 莺 & 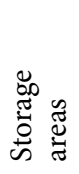 & 芯 & 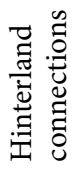 \\
\hline 1. & Marsaxlokk & 1 & 1 & 1 & 1 & 1 & 1 \\
\hline 2. & Piraeus & 1 & 1 & 1 & 1 & 1 & 1 \\
\hline 3. & Barcelona & 1 & 1 & 1 & 1 & 1 & 1 \\
\hline 4. & Gioia Tauro & 1 & 1 & 1 & 1 & 1 & 1 \\
\hline 5. & Taranto & 1 & 1 & 1 & 1 & 1 & 1 \\
\hline 6. & Koper & 0 & 0 & 0 & 0 & 0 & 0 \\
\hline 7. & Rijeka & 0 & 0 & 0 & 0 & 0 & 0 \\
\hline 8. & Trieste & 1 & 1 & 1 & 1 & 1 & 1 \\
\hline 9. & Ravenna & 0 & 0 & 0 & 0 & 0 & 0 \\
\hline 10. & Varna & 0 & 0 & 0 & 0 & 0 & 0 \\
\hline 11. & Odessa & 0 & 0 & 0 & 0 & 0 & 0 \\
\hline 12. & Novorossiysk & 0 & 0 & 0 & 0 & 0 & 0 \\
\hline
\end{tabular}

Notes: ' 0 ' - current capacities are insufficient, optimization is required; ' 1 ' - current capacities are sufficient, optimization is not required.

With the possible rise of trade flows, storage area would represent a problem. The number of containers would increase to the level that without new spaces the terminal would be exposed to congestion and redundant movements of containers. Land equipment is again related to the storage areas so the purchase of additional equipment would be necessary. The decision about the equipment that will be used at the terminal depends on several factors. According to Steenken et al. (2004), the most important factors are related to space restrictions and economic and historic reasons. The situation in the column of the hinterland connections has changed, too. If the value in the preceding table for almost all the ports (with the exception of two) was 1, the results in this table shows almost everywhere a value of 0 , which reflects that a large number of containers at the terminal means the necessity for more powerful connections with the hinterland.

\section{The Analysis for Ports Evaluation Using a DST}

At the end of the simulation, the evaluation of the ports on the basis of the presented DST has been completed. Estimates obtained thus reflect actual situations of the container terminal capacities in the twelve analysed ports.

For the basis of the port assessments, all six factors of the tool were used. For each factor, a grading scale was made (Table 4). The scale was based on the conditions that are necessary for the acceptance of $6000 \mathrm{TEU}$ ships in the port.

Estimates range from 5 to 10 , where 10 is the maximum possible score, and 5 is a minimum estimate. Maximum estimates were determined by the characteristics that a 6000 TEU ship needs at particular part of the terminal, and adapted for the reception of two ships of this size at the terminal simultaneously. 
Table 4. Grading scale

\begin{tabular}{|c|c|c|c|}
\hline Sea depth $[\mathrm{m}]$ & Grade & Berth length [m] & Grade \\
\hline$>13$ & 10 & $>800$ & 10 \\
\hline $12 \div 13$ & 9 & $700 \div 800$ & 9 \\
\hline $11 \div 12$ & 8 & $600 \div 700$ & 8 \\
\hline $10 \div 11$ & 7 & $500 \div 600$ & 7 \\
\hline $9 \div 10$ & 6 & $400 \div 500$ & 6 \\
\hline$<9$ & 5 & $<400$ & 5 \\
\hline Gantry cranes (No) & Grade & Storage area [ha] & Grade \\
\hline$>10$ & 10 & $>30$ & 10 \\
\hline $8 \div 10$ & 9 & $25 \div 30$ & 9 \\
\hline $6 \div 8$ & 8 & $20 \div 25$ & 8 \\
\hline $4 \div 6$ & 7 & $15 \div 20$ & 7 \\
\hline $2 \div 4$ & 6 & $10 \div 15$ & 6 \\
\hline$<2$ & 5 & $<10$ & 5 \\
\hline Land mechanization (actual/ideal) [\%] & Grade & Hinterland connection & Grade \\
\hline$>90$ & 10 & two railway track; highway; inland waterway & 10 \\
\hline $80 \div 90$ & 9 & two railway track; highway & 9 \\
\hline $70 \div 80$ & 8 & one railway track; highway & 8 \\
\hline $60 \div 70$ & 7 & two railway track; regional road & 7 \\
\hline $50 \div 60$ & 6 & one railway track; regional road & 6 \\
\hline$<50$ & 5 & regional road & 5 \\
\hline
\end{tabular}

The maximum score was therefore assigned to the port that meets or exceeds the required capacity that two 6000 TEU ships need in a particular part of the terminal. The estimates were than divided proportionally up to the lowest value of 5 . This score were received in case the capacities at the particular part of the terminal were completely inadequate for the reception of two ships of this size.

The performed analysis allowed us to determinate how many ports are actually ready to accept two such ships at the same time and are therefore in a position to become a port of call for more than one direct service.

The final estimates based on the analysis made are shown in Table 5.

As expected, the five largest ports have the best estimates. The highest were reached in the first four factors of the DST, as those are mainly transhipment ports where the level of productivity depends mainly on the performance of the berth subsystem. In this case, the column with the storage areas and land equipment do not have similar ratings. In storage areas, the estimates for all the ports are very high, which shows that the ports have the proper surface for the movement and storage of greater numbers of containers. In the field of land equipment, the ratings are different, which is attributable mainly to the fact that ports are using different types of equipment, that in the end (on average), brings them a lower score in the table. Such an example is the port of Marsaxlokk, while in the case of Piraeus it turned out that the port is actually using all the analysed equipment (transtainer, straddle carrier, reach stacker, fork lift), but the current capacities are not reaching the desired value. The ports of Gioia Tauro, Barcelona and Taranto also have achieved very high values in this case. Larger ports have very modern links with the hinterland; however, the highest rates were not reached by any port, since none of them can deal with inland waterway connections. The exception in this column is the Marsaxlokk port, which had the lowest score due to its exclusive transhipment function.

Table 5. Ports evaluation

\begin{tabular}{|c|c|c|c|c|c|c|c|c|}
\hline No & Port & 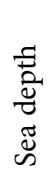 & 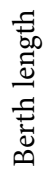 & 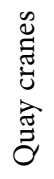 & 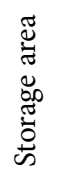 & 芯 & 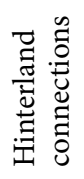 & $\Xi$ \\
\hline 1. & Gioia Tauro & 10 & 10 & 10 & 10 & 10 & 9 & 59 \\
\hline 2. & Barcelona & 10 & 10 & 10 & 10 & 9 & 9 & 58 \\
\hline 3. & Taranto & 10 & 10 & 10 & 9 & 9 & 9 & 57 \\
\hline 4. & Trieste & 10 & 9 & 8 & 10 & 10 & 9 & 56 \\
\hline 5. & Piraeus & 10 & 10 & 10 & 10 & 6 & 9 & 55 \\
\hline 6. & Marsaxlokk & 10 & 10 & 10 & 10 & 8 & 5 & 53 \\
\hline 7. & Koper & 8 & 8 & 7 & 7 & 7 & 8 & 45 \\
\hline 8. & Ravenna & 7 & 8 & 5 & 7 & 8 & 8 & 43 \\
\hline 9. & Rijeka & 8 & 6 & 5 & 5 & 8 & 8 & 40 \\
\hline 10. & Novorossiysk & 7 & 7 & 5 & 6 & 6 & 8 & 39 \\
\hline 11. & Odessa & 8 & 5 & 6 & 5 & 5 & 8 & 37 \\
\hline 12. & Varna & 5 & 6 & 5 & 6 & 5 & 8 & 35 \\
\hline
\end{tabular}


Smaller ports generally scored low. The notable exception is the port of Trieste, which reached very high scores in all the factors considered and is therefore in the fourth place. The analysis shows that among all smaller ports, Trieste already has the most appropriate conditions for receiving 6000 TEUs ships. The second highest ranked small port Koper, in the seventh place. Its estimates ranged between 7 and 8 in all fields. The port has thus very good possibilities to accept more 6000 TEUs ships simultaneously in the future, although optimization in some parts of the terminal is required. Most negative scores (5) were reached by the ports of Odessa and Varna. Ranked lowest, Varna has the most work to do to become a port capable of receiving simultaneous stops of 6000 TEU ships.

The data obtained in (Table 5) shows that for most ports the biggest problems are related to insufficient number of quay cranes, and inadequate land equipment, although through the complete study performed we found that the primary factor that is causing problems for smaller ports in receiving larger ships remains the shallow draft. We can clearly say that only the port of Trieste currently has the capacity and the ability to accept such ships at the terminal without trouble.

Fig. 3 shows the individual assessment that the ports received for each analysed factor. The classification of ports was made according to the calculated average (based on all the estimates obtained).

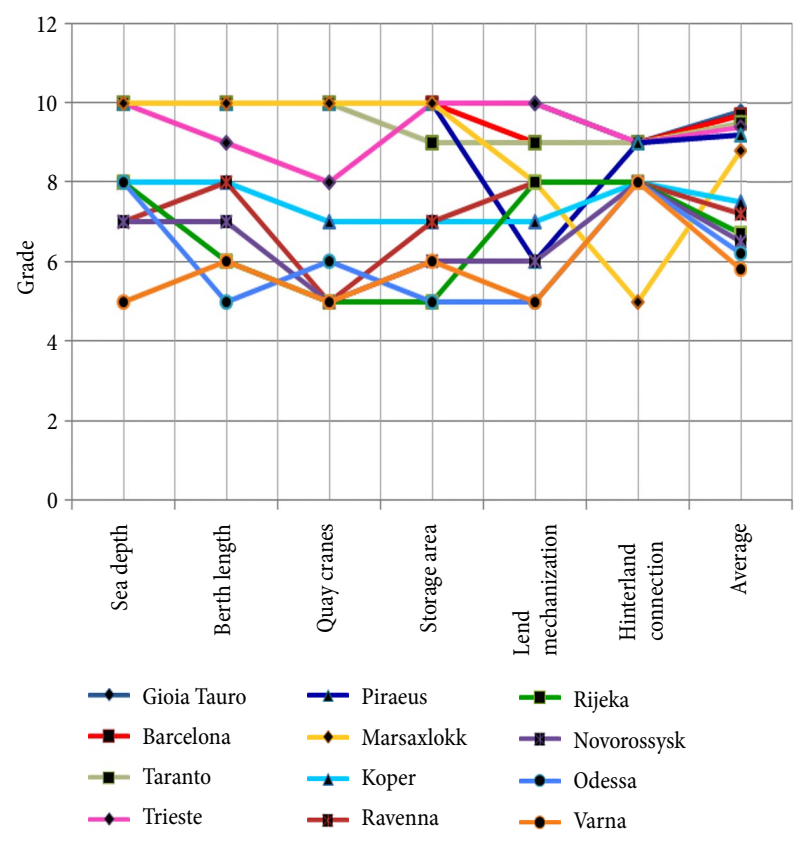

Fig. 3. Final ports assessment

\section{Optimization Results for the Port of Koper}

Luka Koper is the only Slovenian and the main northern Adriatic container port; in 2012 Koper reached a throughput of 570744 TEU. Compared to the year 2011 this represents a 3.2\% drop (589314 TEUs) - the first after the drop in the year 2009.

The terminal business consists of two direct lines to the Far East, a few direct lines with the Mediterranean, but mostly is represented by feeder lines (Stojaković, Twrdy 2010). The current throughput capacity of the terminal is limited to 750000 TEUs, which ranks the terminal in the class of smaller container terminals (detailed characteristics of the terminal are described in Table 6).

The largest container ships currently entering the terminal have a capacity of 6500 TEUs (they are not fully loaded); however the acceptance of such a large ship in port often represents a problem due to the shallow draft of the terminal (it is possible only with high tide). The capacities of the terminal are therefore sufficient for the reception of one larger vessel (up to $300 \mathrm{~m}$ in length) and one smaller vessel (up to $200 \mathrm{~m}$ in length) at the same time.

The main objective of the port is to increase productivity of the terminal and obtain more direct services with larger vessels. With the existing terminal facilities that would actually be possible; however the large ships should not arrive at the terminal simultaneously. Due to the unforeseen delays in schedules and long unloading times (2-3 days per 6000 TEU ship) this often presents a problem.

In order to obtain new deep-sea services at the terminal and be more competitive with neighbouring ports, the port of Koper should increase their capacities in several parts of the terminal.

To determinate which those parts are we used the previously presented DST (Fig. 2).

The simulations were made again on the basis of the 6000 TEU ships. At the left side of the DST we inserted the current capacities of the Koper container terminal (Table 6) and confronted (analysed) them with the requirements that two ships of this size would need at the terminal. By following the sequence of the DST we obtained the results that are shown on the right side of the tool (Fig. 4).

The results:

The simulation showed that in order to accept two larger ships at the terminal simultaneously the port would have to increase the capacities of the terminal in all points of the DST.

Table 6. The values of the input data for the port of Koper

\begin{tabular}{cccccc}
\hline Sea depth & Berth length & Quay cranes & Storage area & Land equipment & Hinterland connections \\
\hline $11.4 \div 12 \mathrm{~m}$ & $600 \mathrm{~m}$ & $4 \mathrm{pp}+4 \mathrm{p}$ & 18 ha & 14 transtainers; & one railway track; \\
& & & reachstackers; & modern highway \\
& & & 6 forklifts & \\
\hline
\end{tabular}

Notes: $\mathrm{p}$ - Panamax crane; $\mathrm{pp}$ - post-Panamax crane. 


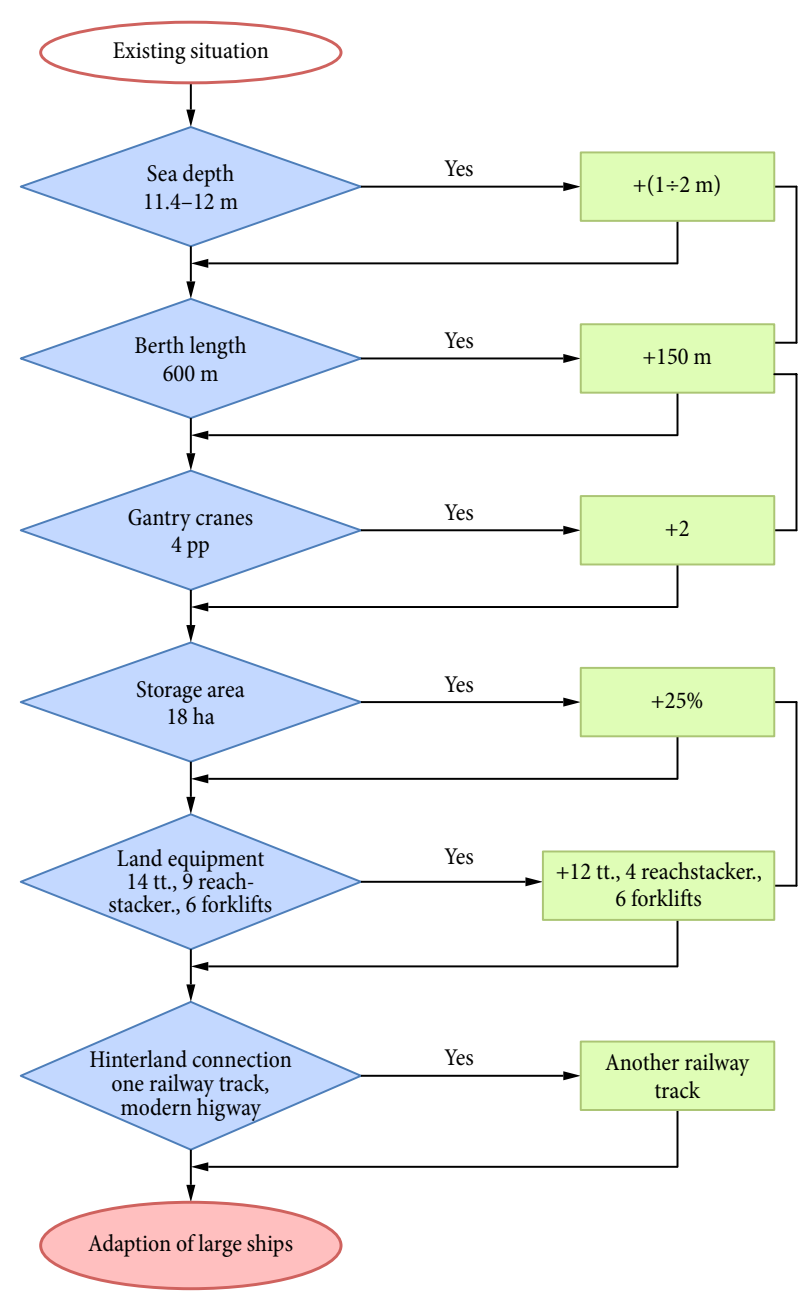

Fig. 4. Optimization results for the port of Koper

The current sea depth would have to increase by a meter or two, as ships of such dimensions require a depth of at least $13 \mathrm{~m}$ to enter a terminal without difficulty, while the pier would have to be extended by 100 to $150 \mathrm{~m}$ in order to provide optimal throughput operations for two (300 $\mathrm{m}$ in length) ships simultaneously. The appropriate extension of the terminal quay would also result in the need to purchase new gantry cranes. The current number of cranes is sufficient for the current terminal capacities, as when the largest ship (6000 TEUs) arrives the 4 post-Panamax cranes are available to attend her, while the other 4 Panamax cranes are used to serve smaller ships at the terminal (Panamax and feeder ships). With the actual terminal capacities the reception of two large ships (6000 TEUs) simultaneously would cause slower operations and consequently delays, and extension of the time the ship spends at the terminal, which would result in increasing costs. As mentioned before, 3 to 5 cranes are necessary for the optimal operation of the 6000 TEU ships. Therefore, the purchase of a minimum of 2 post-Panamax cranes would be necessary.

The arrival of two large ships simultaneously would certainly affect the operations of the other terminal subsystems. The current storage capacities are now barely sufficient, while with the acquisition of new deep-sea services the cargo flows would increase and the storage area would be too small for all the additional containers that would pass through the terminal. The port would therefore have to increase the capacity by approximately $25 \%$. The current equipment at the storage area might be sufficient after the enlargement of the area, but there would exist real risks of delays, which would consequently mean a loss of port efficiency and the risk of losing customers. It would be absolutely necessary to optimize the railway hinterland connections of the port. Today the link from the port to its hinterland is possible by road and rail traffic; although the railway capacities are already fully exploited (60\% of containers comes/ goes to the hinterland markets by rail). The construction of another railway track would therefore be of vital importance.

The analysis showed that with the current capacities the port is able to accept one ship of 6000 TEUs and one smaller ship of around $3000 \div 4000$ TEUs at the terminal simultaneously, while the acceptance of two larger ships at the same time is still not possible. The port will therefore have to improve several parts of the terminal in the near future if it wishes to compete effectively with the neighbouring ports of Trieste and Rijeka.

\section{Conclusions}

With the done survey we came to the conclusion that constant growth in container transport and in container fleet rendered a large number of ports in this part of the world (Mediterranean) insufficiently prepared for the reception of post-Panamax ships. In particular, smaller ports (from 6 to 12 in the table) have great difficulty in accepting ships of 6000 TEUs capacity. They are therefore unable to compete with larger Mediterranean ports. If these ports do not upgrade the capacities of their existing terminals in time, their positions will be even more difficult in the future. Larger ports will therefore become even more important, while smaller ports will became relatively even smaller, which in the end will lead to the loss of a significant market share and competitiveness in the area. Therefore, smaller ports have to organize themselves and invest in their infrastructure and suprastructure to remain competitive at the market.

Ocean carriers, in establishing links with smaller Mediterranean ports, still prefer direct services with

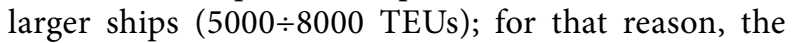
adoption of such vessels for them is absolutely necessary. Carriers cannot wait - they require rapid transhipment and reduced costs for their ships in the port immediately.

Our study intended to illustrate the main problems facing smaller Mediterranean ports today in accepting larger ships at the terminal and to identify the problems that will arise if they would like to be a port of call for more direct services that employ post-Panamax ships. The results showed that most problems are caused by inadequate sea depth and inadequate quay cranes, while in the case of the acceptance of two or more larger ship at the terminal simultaneously the problems extend 
to all the analysed factors. Among the ports only the first five (Marsaxlokk, Piraeus, Barcelona, Gioia Tauro and Taranto) and the port of Trieste currently have the means to accept two or more large ships at the terminal simultaneously, as only their capacities satisfy the requirements in all the factors of the DST. It is thus clear that the 'battle' will be between those smaller ports that are in close proximity and have similar capacities, as competition with larger ports would make no sense in that it will have been lost early on.

The tool created, along with the survey, proved to be good and reliable for decision-making, as it has enabled the analysis with the application of real data of the selected ports and consequently the identification of the weaknesses in capacities of each analysed port (terminal). It was therefore possible to determinate the major problems in the terminal capacities that are facing smaller Mediterranean ports today when they strive to become a port of call in a carrier's direct service.

This paper has presented the DST for the determination of the measures that will be necessary for the ports if they want to increase their current terminal capacities and be competitive in the marketplace that requires from them constant adaptation to the market trends. To achieve even more accurate and detailed results that will facilitate the decisions of terminal operators and satisfy their needs it would be necessary to do some further research and develop the presented optimization methodology. Furthermore, container terminal optimization offers significant potential for research, which can be obtained through different applications.

\section{References}

Álvarez, J. F.; Longva, T.; Engebrethsen, E. S. 2010. A methodology to assess vessel berthing and speed optimization policies, Maritime Economics \& Logistics 12(4): 327-346. http://dx.doi.org/10.1057/mel.2010.11

Beškovnik, B. 2008. Measuring and increasing the productivity model on maritime container terminals, Pomorstvo 22(2): 171-183.

Beškovnik, B.; Twrdy, E. 2010. Planning organization and productivity simulation tool for maritime container terminals, Transport 25(3): 293-299.

http://dx.doi.org/10.3846/transport.2010.36

Bierwirth, C.; Meisel, F. 2010. A survey of berth allocation and quay crane scheduling problems in container terminals, European Journal of Operational Research 202(3): 615-627. http://dx.doi.org/10.1016/j.ejor.2009.05.031

Cullinane, K.; Khanna, M. 1999. Economies of scale in large container ships, Journal of Transport Economics and Policy 33(2): 185-207.

Dai, J.; Lin, W.; Moorthy, R.; Teo, C.-P. 2008. Berth allocation planning optimization in container terminals, International Series in Operations Research \& Management Science 119: 69-104. http://dx.doi.org/10.1007/978-0-387-75240-2_4

Dragović, B.; Park, N. K.; Radmilović, Z.; Maraš, V. 2005. Simulation modelling of ship-berth link with priority service, Maritime Economics \& Logistics 7(4): 316-335. http://dx.doi.org/10.1057/palgrave.mel.9100141
Dragović, B.; Park, N. K.; Radmilović, Z. 2006a. Ship-berth link performance evaluation: simulation and analytical approaches, Maritime Policy \& Management 33(3): 281-299. http://dx.doi.org/10.1080/03088830600783277

Dragović, B.; Zrnić, D.; Radmilović, Z. 2006b. Ports \& Container Terminals Modeling: research monograph. University of Belgrade, Serbia. 214 p.

Froyland, G.; Koch, T.; Megow, N.; Duane, E.; Wren, H. 2008. Optimizing the landside operation of a container terminal, OR Spectrum 30(1): 53-75. http://dx.doi.org/10.1007/s00291-007-0082-7

Günther, H.-O.; Kim, K.-H. 2006. Container terminals and terminal operations, OR Spectrum 28(4): 437-445. http://dx.doi.org/10.1007/s00291-006-0059-y

Jansson, J. O.; Shneerson, D. 1982. The optimal ship size, Journal of Transport Economics and Policy 16(3): 217-238.

Kassembe, E.; Gang, Z. 2011. The impact of ship size on its unit cost, in Proceedings of the 2011 International Conference on Transportation, Mechanical, and Electrical Engineering (TMEE), 16-18 December 2011, Changchun, China, 1826-1830. http://dx.doi.org/10.1109/TMEE.2011.6199569

Le-Griffin, H. D.; Murphy, M. 2008. Assessing Container Terminal Productivity: Experiences of the Ports of Los Angeles and Long Beach. METRANS Applied Research Project AR-0506. METRANS Transportation Center. 35 p. Available from Internet: http://www.metrans.org/sites/default/files/research-project/AR\%2005-06\%20Final\%20Report_0_0.pdf

Lee, L. H.; Chew, E. P.; Tan, K. C.; Han, Y. 2006. An optimization model for storage yard management in transshipment hubs, OR Spectrum 28(4): 539-561. http://dx.doi.org/10.1007/s00291-006-0045-4

Liang, C.; Hwang, H.; Gen, M. 2012. A berth allocation planning problem with direct transshipment consideration, Journal of Intelligent Manufacturing 23(6): 2207-2214. http://dx.doi.org/10.1007/s10845-011-0566-9

Murty, K. G.; Liu, J.; Wan, Y.-W.; Linn, R. 2005. A decision support system for operations in a container terminal, Decision Support Systems 39(3): 309-332. http://dx.doi.org/10.1016/j.dss.2003.11.002

Salido, M. A.; Rodriguez-Molins, M.; Barber, F. 2012. A decision support system for managing combinatorial problems in container terminals, Knowledge-Based Systems 29: 6374. http://dx.doi.org/10.1016/j.knosys.2011.06.021

Seyedalizadeh Ganji, S. R.; Babazadeh, A.; Arabshahi, N. 2010. Analysis of the continuous berth allocation problem in container ports using a genetic algorithm, Journal of $\mathrm{Ma}$ rine Science and Technology 15(4): 408-416. http://dx.doi.org/10.1007/s00773-010-0095-9

Stahlbock, R.; Voß, S. 2008. Operations research at container terminals: a literature update, OR Spectrum 30(1): 1-52. http://dx.doi.org/10.1007/s00291-007-0100-9

Steenken, D.; Voß, S.; Stahlbock, R. 2004. Container terminal operation and operations research - a classification and literature review, OR Spectrum 26(1): 3-49. http://dx.doi.org/10.1007/s00291-003-0157-z

Stojaković, M.; Twrdy, E. 2010. Opportunities for the increase of cargo handling capacity at the container terminal in the port of Luka Koper, in Proceedings of the International Conference on Transport Science (ICTS), May 2010, Portorož, Slovenia (CD).

Sys, C.; Blauwens, G.; Omey, E.; Van de Vorde, E.; Witlox, F. 2008. In search of the link between ship size and operations, Transportation Planning and Technology 31(4): 435463. http://dx.doi.org/10.1080/03081060802335109 
Tongzon, J.; Heng, W. 2005. Port privatization, efficiency and competitiveness: some empirical evidence from container ports (terminals), Transportation Research Part A: Policy and Practice 39(5): 405-424.

http://dx.doi.org/10.1016/j.tra.2005.02.001

Twrdy, E.; Beškovnik, B. 2008. Planning and decision-making to increase productivity on a maritime container terminal, Promet - Traffic\& Transportation 20(5): 335-341.

UNCTAD. 2011. Review of Maritime Transport 2011. United Nations Conference on Trade and Development. Available from internet: http://unctad.org

UNCTAD. 2012. Review of Maritime Transport 2012. United Nations Conference on Trade and Development. Available from internet: http://unctad.org

Vacca, I.; Salani, M.; Bierlaire, M. 2010. Optimization of operations in container terminals: hierarchical vs integrated approaches, in Proceedings of the 10th STRC Swiss Transport Research Conference, 1-3 September, Ascona, Switzerland, 1-16. Available from internet: http://www.strc.ch/conferences/2010/Vacca.pdf

Van Hee, K. M.; Wijbrands, R. J. 1988. Decision support system for container terminal planning, European Journal of Operational Research 34(3): 262-272.

http://dx.doi.org/10.1016/0377-2217(88)90147-6

Vis, I. F. A.; De Koster, R. 2003. Transshipment of containers at a container terminal: an overview, European Journal of Operational Research 147(1): 1-16. http://dx.doi.org/10.1016/S0377-2217(02)00293-X

Watanabe, I. 2001. Container Terminal Planning: A Theoretical Approach. WCN Publishing. 245 p.

Wiegmans, B.W.; Van der Hoest, A.; Notteboom, T. E. 2008. Port and terminal selection by deep-sea container operators, Maritime Policy \& Management 35(6): 517-534. http://dx.doi.org/10.1080/03088830802469329

Yeo, G.-T.; Roe, M.; Dinwoodie, J. 2008. Evaluating the competitiveness of container ports in Korea and China, Transportation Research Part A: Policy and Practice 42(6): 910921. http://dx.doi.org/10.1016/j.tra.2008.01.014

Zhang, C.; Liu, J.; Wan, Y.-W.; Murty, K. G.; Linn, R. J. 2003. Storage space allocation in container terminals, Transportation Research Part B: Methodological 37(10): 883-903. http://dx.doi.org/10.1016/S0191-2615(02)00089-9 